\title{
On the impact of the Bimodal Oscillating System (BiOS) on the biogeochemistry and biology of the Adriatic and Ionian Seas (Eastern Mediterranean)
}

\author{
G. Civitarese ${ }^{1}$, M. Gačić ${ }^{1}$, M. Lipizer ${ }^{1}$, and G. L. Eusebi Borzelli ${ }^{2}$ \\ ${ }^{1}$ Istituto Nazionale di Oceanografia e di Geofisica Sperimentale - OGS, Dip. di Oceanografia, \\ B.go Grotta Gigante 42/c, 34010 Sgonico (Trieste), Italy \\ ${ }^{2}$ Telespazio S.p.A., via Tiburtina 965, 00156 Rome, Italy \\ Received: 2 August 2010 - Published in Biogeosciences Discuss.: 14 September 2010 \\ Revised: 30 November 2010 - Accepted: 9 December 2010 - Published: 15 December 2010
}

\begin{abstract}
Analysis of 20-year time-series of the vertically averaged salinity and nutrient data in the Southern Adriatic shows that the two parameters are subject to strong decadal variability. In addition, it is documented that nutrient and salinity variations are out of phase. Nutrients in the Ionian and in the Adriatic vary in parallel except that generally the nutrient content in the Adriatic is lower than in the Ionian, a fact that has been attributed to primary producer consumption following the winter convective mixing. As shown earlier, North Ionian Gyre (NIG) changes its circulation sense on a decadal scale due to the Bimodal Oscillating System, i.e. the feedback mechanism between the Adriatic and Ionian. Cyclonic circulation causes a downwelling of the nitracline along the borders of the NIG and a decrease in the nutrient content of the water flowing into the Adriatic across the Otranto Strait, and vice versa. In addition, the highly oligotrophic central area of the Ionian shows annual blooms only during cyclonic NIG circulation. Inversion of the sense of the NIG results in the advection of Modified Atlantic Water or of the Levantine/Eastern Mediterranean waters in the Adriatic. Here, we show that the presence of allochtonous organisms from Atlantic/Western Mediterranean and Eastern Mediterranean/temperate zone in the Adriatic are concurrent with the anticyclonic and cyclonic circulations of the NIG, respectively. On the basis of the results presented, a revision of the theory of Adriatic ingressions formulated in the early 1950 s is proposed.
\end{abstract}

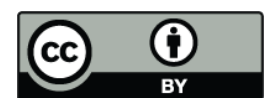

Correspondence to: G. Civitarese (gcivitarese@ogs.trieste.it)

\section{Introduction}

The Southern Adriatic (SA) is a circular basin, the deepest part of the Adriatic Sea ( $1250 \mathrm{~m}$ deep) (Fig. 1). Its circulation is characterized by a topographically trapped cyclonic gyre. In its center, the Adriatic Dense Water (AdDW) formation takes place via open-ocean winter convection. Salty intermediate water from the Ionian Sea (IS) entering in the SA through the Otranto Strait represents a preconditioning factor for the AdDW formation process. The AdDW feeds the deep thermohaline cell of the Eastern Mediterranean (EMed), being the main component of the Eastern Mediterranean Dense Water (EMDW).

The dynamics of the Southern Adriatic (SA) and Ionian Sea (IS) (Fig. 1) are intimately linked by means of the Bimodal Oscillating System (BiOS) mechanism that changes the circulation of the North Ionian Gyre (NIG) from cyclonic to anticyclonic and viceversa, on decadal time scale (Fig. 5a and b). To summarize, it has been shown that, at least in the last 20 years, variability in the upper-layer Ionian circulation has been primarily driven by changes in the thermohaline processes associated with modifications in the properties of Adriatic Dense Water (AdDW) outflowing through the Strait of Otranto (Gačić et al., 2010). When the NIG is anticyclonic, the Modified Atlantic Water (MAW) coming from the Sicily Channel is in part deviated toward the northern Ionian and eventually enters the SA, decreasing the salinity and the density of the AdDW. The change in the properties of the outflowing AdDW causes a progressive weakening of the anticyclonic upper-layer circulation in the IS; the circulation finally reverses, modifying the pathways of the water masses. In fact, the cyclonic NIG suppresses the northern branch of the MAW flow and favours the rapid advection

Published by Copernicus Publications on behalf of the European Geosciences Union. 


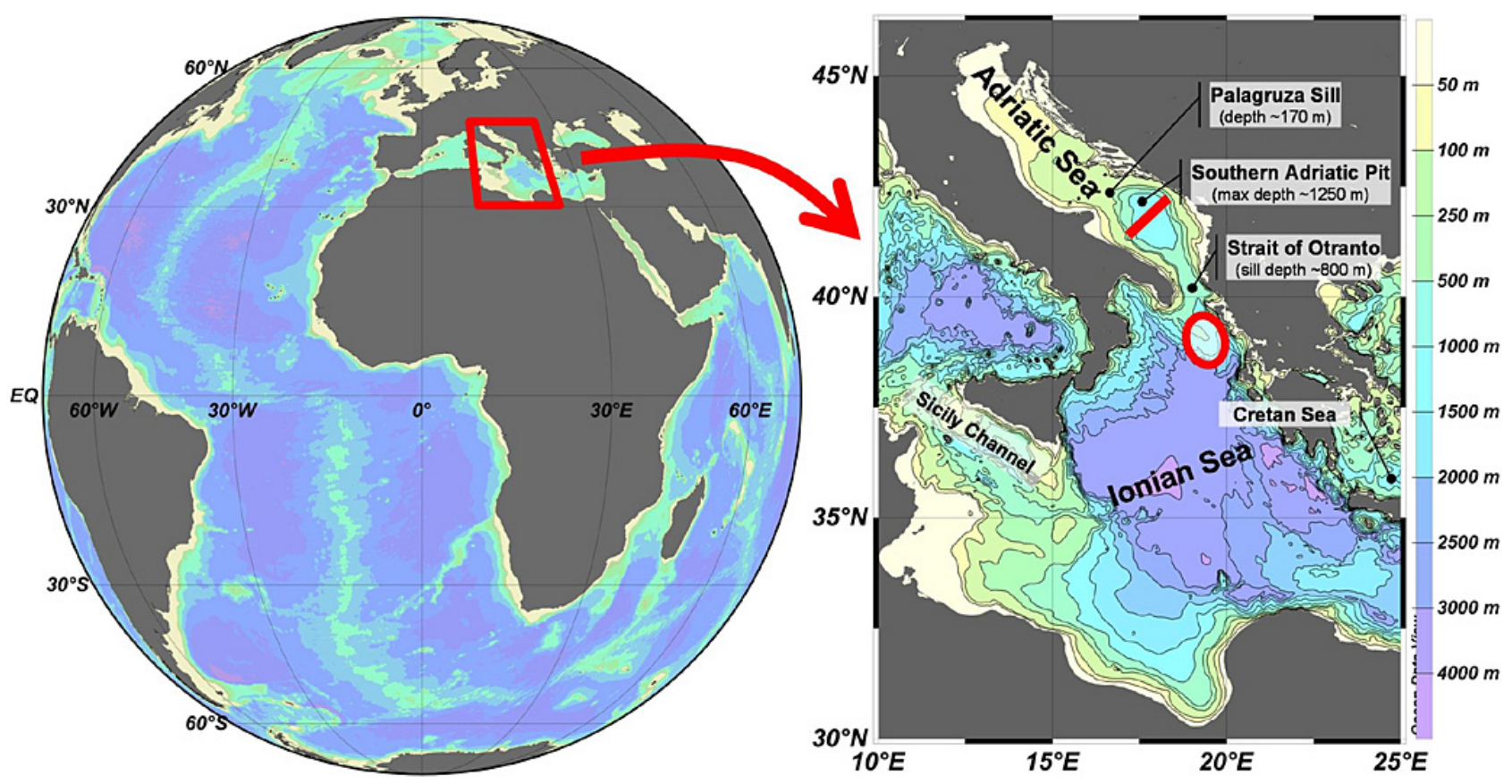

Fig. 1. Study area. Red line and red ellipse indicate the area from which the data used in the averaged time series were collected.

of salty Levantine and/or Cretan Intermediate Water (LIW; CIW) along the eastern flank of the IS into the SA. This results in an increase in the salinity (and density) of AdDW outflowing into the IS that gradually impairs the cyclonic NIG, eventually reversing it to an anticyclone.

Here, we will focus our attention on the possible impact of the BiOS mechanism on the biogeochemistry (Sect. 3) of the Adriatic-Ionian system, in terms of decadal variability of the nutrient pool in the SA (Sect. 3.1), and of nutricline dynamics in the Ionian Sea (Sect. 3.2). In Sect. 3.3 we revised the theory of "Adriatic ingression" formulated for the first time by Buljan (1953). The impacts of the BiOS mechanism on the Adriatic and Ionian ecosystems (Sect. 4) are illustrated in Sects. 4.1 and 4.2, respectively, with more emphasis on the possible impact on the Adriatic biodiversity (Sect. 4.2.1). The Summary and conclusions (Sect. 5), and the List of acronyms (Table A1) used in the text conclude the paper.

\section{Materials and methods}

Several datasets collected in the period 1987-2008 in the SA and in the IS, within the framework of national and international research projects, were used in this work (Table 1). For the Ionian, the averaged nitrate time series refers to a number of stations varying from year to year, located in the northeastern region, as indicated by the red ellipse in Fig. 1. For the SA, stations deeper than $800 \mathrm{~m}$, located in the central area of the basin, were selected along the Bari-Dubrovnik transect (typically five stations per cruise), as indicated by the red line in Fig. 1. Both in SA and in the IS, the nitrate average was calculated in the layer $200-800 \mathrm{~m}$, from a number of samples per station varying from 4 to 10 . Salinity data are the same as used in Gačić et al. (2010). Nitracline depth (depth of [nitrate $]=3 \mu \mathrm{M}$ ) distributions in the IS derived from nitrate data collected during the oceanographic campaigns (Table 1) are presented in Fig. 4.

Nitrate concentrations (here considered as the sum of nitrate and nitrite concentrations) were determined immediately after collection on board (when possible) or within two weeks of storage at $-20^{\circ} \mathrm{C}$ in an onshore laboratory, by means of a hybrid autoanalyzer equipped with a Chemlab continuous flow colorimeter, according to the method reported by Grasshoff (1983) with slight modifications. Repeated comparisons among samples analyzed on board and on shore never showed appreciable differences. The short-term precision was usually determined in five replicates of seawater samples. The coefficient of variation $(\mathrm{Cv}(\%)=100 \times$ standard deviation/mean $)$ was better than $2 \%$.

\section{The BiOS mechanism and the biogeochemical dynamics of the Adriatic-Ionian system}

During the 1990s, the EMed experienced significant variations on the basin scale as a response to the change in the deep thermohaline cell. The area of dense water formation switched from the SA to the Cretan Sea. This change, 
Table 1. Oceanographic campaigns originating the data used in the present work.

\begin{tabular}{llll}
\hline Year & Oceanographic Campaign & Vessel & Area \\
\hline 1985 & POEM-01-85 & Bannock (I) & IS \\
1986 & POEM-03-86 & Bannock (I) & IS \\
1987 & POEM-AS-87 & Meteor (D) & AS \\
1990 & AM-1 & Bannock (I), Meteor (D) & IS \\
1991 & POEM-BC-O91 & Bannock (I) & AS \\
1992 & AM-2 & Bannock (I), Aegaeo (GR) & IS \\
1992 & POEM-BC-A92 & A. N. Strakhov (I) & AS \\
1993 & AM-3 & Urania (I) & AS, IS \\
1995 & M31 & Meteor (D) & AS \\
$1997-1999$ & MATER-1 - MATER-10 & Urania (I) & IS \\
1999 & SINAPSI-3 & Urania (I) & AS, IS (MATER-2) \\
2002 & SINAPSI-4 & Urania (I) & AS, IS \\
2005 & STRATA-05 & Urania (I) & AS, IS \\
$2006-2008$ & VECTOR-AM1 - VECTOR-AM7 & Universitatis (I), Dallaporta (I) & AS \\
2008 & SESAME-IT1 & Urania (I) & IS \\
\hline
\end{tabular}

known as the Eastern Mediterranean Transient (EMT), produced modifications in water mass characteristics and circulation in the entire EMed (Roether et al., 1996; Klein et al., 1999). Klein et al. (1999) compared the new transient state of the EMed with the situation registered in 1987. Considering the outflow of Cretan Sea Outflow Water (CSOW) from the Aegean at a rate of $1.0 \mathrm{~Sv}$, major changes occurred abruptly in the deep layers but other significant modifications involved almost the entire water column. In particular, Klein et al. (1999) concluded that the changes in the vertical distribution of water masses, a consequence of the massive CSOW outflow, were associated with a noticeable upward nutrient transport due to a rise in the nutricline, more pronounced (about $150 \mathrm{~m}$ ) in the eastern IS.

In 1997, the NIG turned from anticyclonic to cyclonic (Larnicol et al., 2002; Manca et al., 2002). This reversal was also ascribed by Borzelli et al. (2009) to the massive inflow of CSOW associated with the EMT. Subsequently, Gačić et al. (2010) generalized the concept, showing that the NIG inversions are due to internal processes caused by the interactions of the Ionian upper-layer circulation and the outflow of the AdDW. These conclusions were supported by the fact that decadal variations in the vertically averaged salinity and density in the SA are coherent with changes in the sea level height and the surface geostrophic flow in the northern Ionian. The BiOS mechanism formulated by the authors implies that the NIG oscillates between the cyclonic and anticyclonic modes on a decadal time scale.

\subsection{The decadal variability in the nutrient pools in the Southern Adriatic}

Reversals of the NIG have an important impact on the water masses that enter the Adriatic via the Otranto Strait. Therefore, this area of the SA should be an appropriate "sensor" for studying the effect of advection of different water masses associated with diverse upper-layer circulation patterns in the IS (Gačić et al., 2010). Together with the thermohaline properties, as already reported by Gačić et al. (2010), a biogeochemical time-series was collected in the SA from 1987. In particular, the nitrate + nitrite concentrations averaged in the layer $200-800 \mathrm{~m}$ in the center of the $\mathrm{SA}\left(\mathrm{NO}_{3}^{\mathrm{SA}}\right.$ hereafter) was chosen as a synthetic "tracer" for the biogeochemical dynamics in the sub-basin. Here, the winter vertical mixing takes place and thus the averaged biogeochemical properties represent an integrated response to the advection and to the biological pump consumption (Civitarese and Gačić, 2001). Figure 2 shows the complete $\mathrm{NO}_{3}^{\mathrm{SA}}$ time-series, together with a similar time-series for nitrate in the north eastern Ionian ( $\mathrm{NO}_{3}^{\mathrm{IS}}$ hereafter). The time-series presented here are a continuation of those already reported in Civitarese and Gačić (2001).

In the period 1988-1998 $\mathrm{NO}_{3}^{\mathrm{SA}}$ almost doubled, passing from 3.5 to about $6.0 \mu$ moles $\mathrm{dm}^{-3}(\mu \mathrm{M})$. Then, from 1998 until 2005, nitrate concentration decreased, reaching a minimum value of $2.4 \mu \mathrm{M}$. It is interesting to note that most of the decrease occurred in less than one year, from 1998 to 1999. From 2005 to $2008, \mathrm{NO}_{3}^{\mathrm{SA}}$ increased again to about $4.3 \mu \mathrm{M}$.

The $\mathrm{NO}_{3}^{\mathrm{IS}}$ (Fig. 2) shows similar variability as $\mathrm{NO}_{3}^{\mathrm{SA}}$, with maximum and minimun occurring in the same periods. This is expected as the north-eastern Ionian is considered the source area for the water advected into the SA. During 


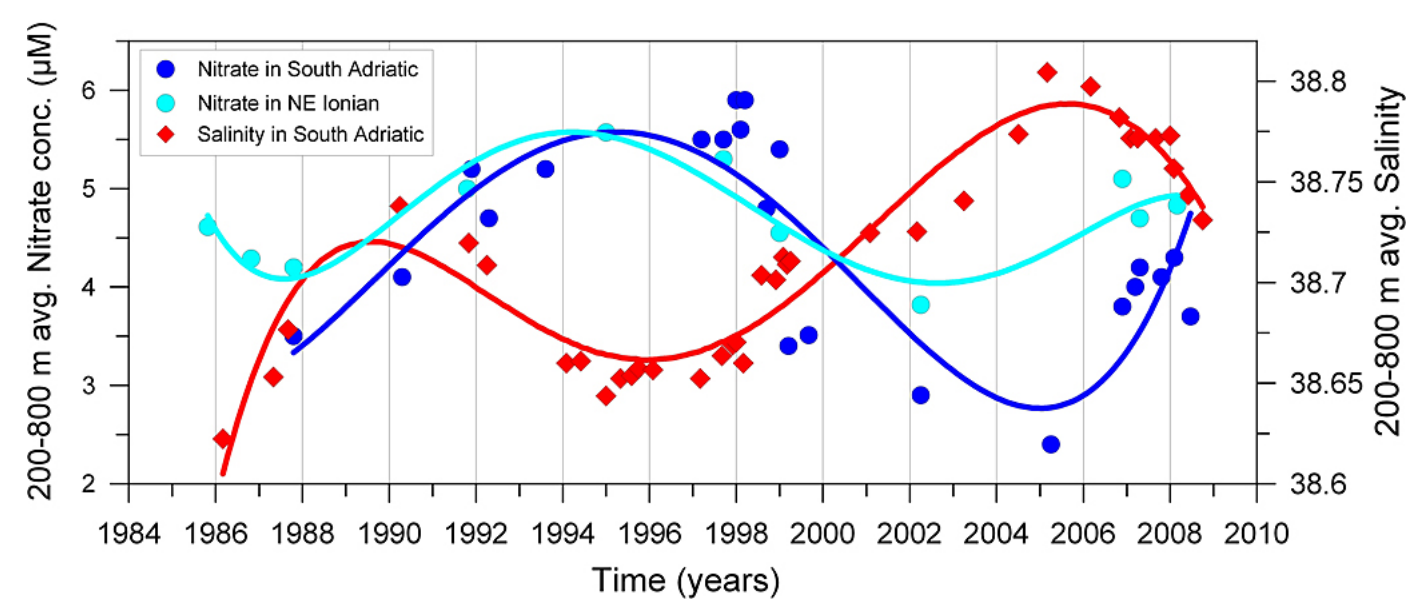

Fig. 2. Time series of salinity in the Southern Adriatic and nitrate in the Southern Adriatic and in the northeastern Ionian averaged over the depth of the $200-800 \mathrm{~m}$ layer. For clarity, data are fitted by polynomial curves.

periods of strong winter convection, as before 1988 and after 1998, the relative nutrient impoverishment of the SA in comparison with the IS was due to the vertical mixing, which diluted the nutrients in a larger volume of water including the upper layer, making them available for consumption by autotrophic organisms (Civitarese and Gačić, 2001).

The increase in $\mathrm{NO}_{3}^{\mathrm{SA}}$ in Fig. 2 from 1988 to 1998 was ascribed by Civitarese and Gačić (2001) to the impact of the EMT on the nitrate pool in the Ionian $\left(\mathrm{NO}_{3}^{\mathrm{IS}}\right)$. The CSOW, intruding into the deepest layer of the Ionian, uplifted the nutricline and the nutrient maximum layer, allowing nutrientricher water to be advected over the sill of Otranto Strait ( $\sim 800 \mathrm{~m}$ deep) into the SA. However, the authors were not able to explain why the increase had already started in 1988, well before the EMT occurrence.

\subsection{Nutricline dynamics in the Ionian Sea}

In order to understand what really happened in the IS in the late 1980s and 1990s, which in turn determined what was observed in the SA, we examined the horizontal distributions of the nitracline depths, defined (as in Klein et al., 1999) as the depth at which the nitrate concentration is $3 \mu \mathrm{M}$, obtained from four oceanographic campaigns in 1987, 1991, 1995, and 1999 (Fig. 3a-d). Note that, as nitrate can be considered representative of the nutrients in general, we will use the terms nitracline and nutricline as synonyms.

As previously described (Malanotte-Rizzoli et al., 1997, 1999; Klein et al., 1999), in 1991 and in 1995 the Ionian basin was characterized by an anticyclonic circulation, stronger and better organized in 1991 than in 1995. Note that the coarser resolution in 1995 (Fig. 3c) does not allow a detailed comparison between the mesoscale structures of the two years, as for example the Pelops gyre, clearly evident in 1991 (Fig. 3b) in front of the Western Cretan Arc Straits but absent in 1995, though clearly present in the SLA map (see
Fig. 2c in Gačić et al., 2010). The nutricline depths along the eastern flank of the IS, i.e. along the border of the anticyclone, in both years were shallower by about $150 \mathrm{~m}$ or more with respect to what was registered in 1987 (Fig. 3a), without showing any significant difference between 1991 and 1995.

It should be noted that in 1987 the IS was already characterized by an anticyclonic meander that occupied the western portion of the Ionian, advecting the MAW into the interior of the basin (Malanotte-Rizzoli et al., 1997). On the other hand, the analysis by Marullo et al. (1997) of the winter time series of sea surface temperature distributions, as quoted by D'Ortenzio et al. (2003), support the hypothesis of the presence of a cyclonic circulation in the IS until 1989. This apparent disagreement could derive from the fact that during the second half of the 1980s the NIG was presumably reversing from cyclonic to anticyclonic and thus devoid of any clear basin-scale circulation pattern, as shown by Gačić et al. (2010) for the subsequent reversals in 1997 and 2006.

The spatial pattern of the horizontal distribution of the nutricline depth is similar for 1991 and 1995. Klein (1999) invoked the impact of the CSOW in uplifting the nutricline in 1995, but this mechanism cannot be responsible for the 1991 distribution since at that time the CSOW was not present in the area. Rather, the nutricline shoaling could be attributed to the upwelling taking place along the boundary of the anticyclonic NIG, both in 1991 and in 1995. On the other hand, the nutricline distribution in 1999 (Fig. 3d) represents a mirror image of those of 1991 and 1995. A deeper nutricline was observed along the flanks of the IS due to a strong cyclonic NIG and, consequently, along its perimeter downwelling took place. At the same time, in the central portion of the basin a shallower nutricline horizon was evident due to the upwelling in the center of the cyclonic NIG. These facts show that, rather than being the effect of the CSOW deep intrusion, the vertical distribution of the oceanographic properties and the displacement of the interfaces (as the nutricline) 


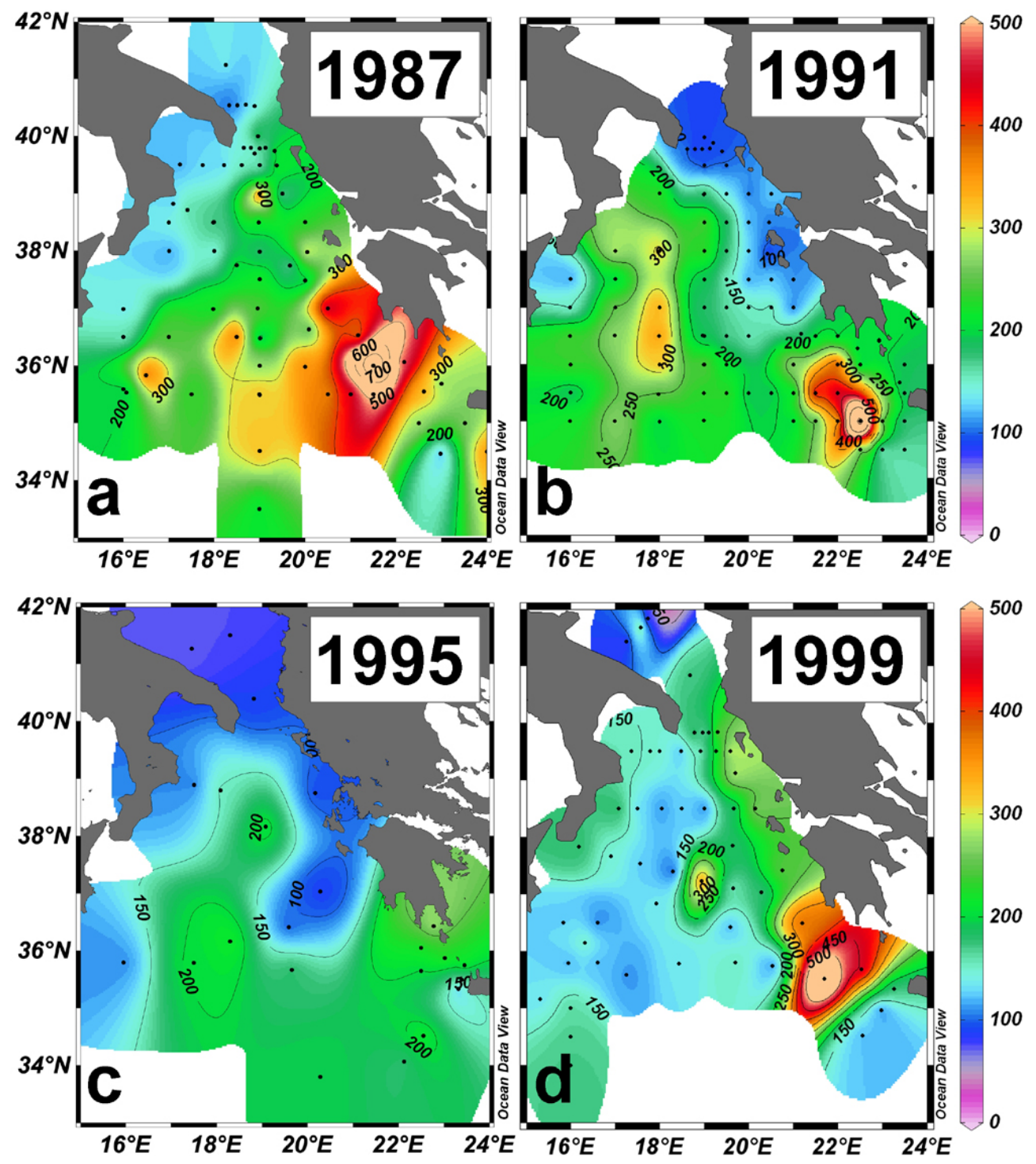

Fig. 3. Nutricline (depth of $[$ nitrate] $=3 \mu \mathrm{M}$ ) horizontal distributions in the Ionian Sea in (a) 1987, (b) 1991, (c) 1995 and (d) 1999. Depth in meters.

are due to the dynamic adjustment related to the particular circulation regime of the NIG. As shown in Fig. 3, the vertical displacements of the nutricline implies equivalent motions of a larger portion of the water column, with the consequent variation in the integrated quantity of $\mathrm{NO}_{3}^{\mathrm{IS}}$, which results in the behaviour reported in Fig. 2.

\subsection{The theory of "Adriatic ingression" needs a revision}

In the early 1950s Buljan (1953) showed strong decadal variability in the salinity of the SA. Buljan called the highsalinity events "Adriatic ingressions" and explained them in terms of the intensifications of the EMed water inflow in the Adriatic. In parallel he concluded, although with few nutrient data, that these high-salinity events should coincide with the nutrient enrichment and higher productivity periods. Subsequently, a number of papers have tried to document "Adriatic ingressions" and connect them with an increase in the primary production. Although quite long and high quality time-series of the primary production data exist in some areas along the eastern coast, we sustain that such a relationship has not been shown clearly. For example, Marasović et al. (1995), analyzing the 1965-1982 data series of salinity and primary production at a middle Adriatic open-sea station, found a statistically significant correlation coefficient of 0.38 . From a visual examination of Fig. 4 of that paper, it seems that most of the positive correlation can be ascribed to the period after 1980, when an increase in salinity was concomitant with an increase in primary production. The rest of the time-series does not show any relevant correlation 


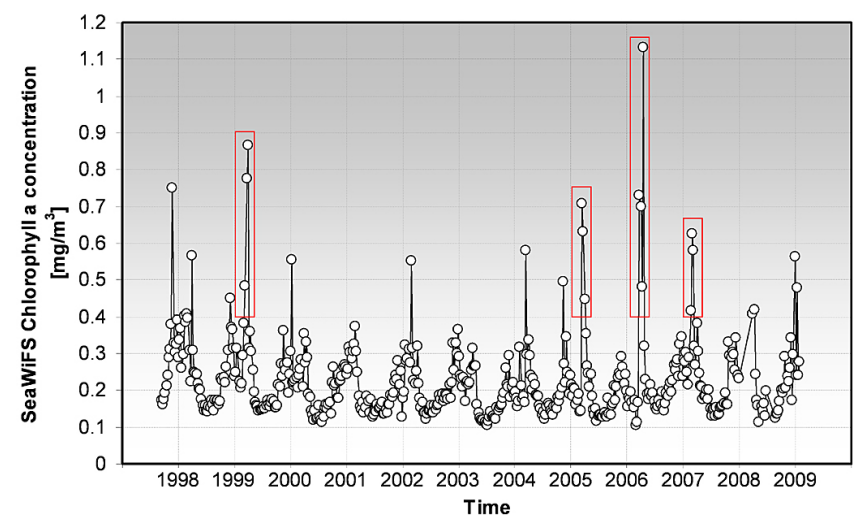

Fig. 4. SeaWiFS 8-day average Chlorophyll-a concentration time series for the area $\left(41.5^{\circ} \mathrm{N}-42.0^{\circ} \mathrm{N}, 17.5^{\circ} \mathrm{E}-18.0^{\circ} \mathrm{E}\right)$ in the SA (data produced by NASA at http://reason.gsfc.nasa.gov/OPS/ Giovanni/ocean.swf8D.2.shtml\#description). Red rectangles indicate periods with intense biomass blooms.

whatsoever. In fact, as stated by the authors, the correlation coefficient between the two parameters jumps to a value of 0.57 when considering only the period after 1975 . Although the authors claimed that the high positive correlation coefficient was an indication of the relationship between salinity and primary production, this analysis cannot be considered sufficiently robust.

In fact, our data from the last 20 years show that the highsalinity events have been associated with low nitrate concentrations and thus any positive correlation between the primary production and salinity is very unlikely to exist. In Fig. 2, the time-series of salinity averaged over the 200$800 \mathrm{~m}$ layer in the SA is superimposed on the nitrate plots. The salinity shows interannual and decadal variability on the same time scales as nutrients, but the two curves are out of phase. This can be explained in terms of two distinct aspects that are involved in the BiOS mechanism and related to each other due to dynamics: (i) the vertical displacement of the interfaces (as shown before), and (ii) the different water masses advected into the Adriatic as related to the two circulation regimes of the NIG. Concerning the first point, the circulation regime of the NIG determines upwelling (when anticyclonic) or downwelling (when cyclonic) of the nutricline and of the nutrient maximum layer along its border. Upwelling and downwelling determine the nutrient enrichment and impoverishment, respectively, of the layer $200-800 \mathrm{~m}$ affected by the northward advection over the sill of Otranto into the Adriatic. The second point implies that the fresher MAW is advected towards the Adriatic by the anticyclonic NIG, whilst the cyclonic NIG prevents the direct intrusion of MAW into the northern Ionian, favouring the rapid advection of saltier waters of Aegean/Levantine origin along the eastern flank of the IS and over the sill of the Otranto Strait. The combined effects of the BiOS mechanism are therefore a concomitant decrease in salinity and increase in nutrients in the SA with an anticyclonic NIG or vice versa with a cyclonic NIG.

One important consequence of the present work is thus a revision of the theory of "Adriatic ingressions" as defined by Buljan (1953) and then recalled in a series of papers over the second half of the last century. As mentioned, decadal occurrences of salinity maxima in the Adriatic were explained in terms of stronger inflow of Levantine waters. That theory also suggests that higher salinity waters are at the same time richer in nutrients as the EMed should be a source of nutrients for the Adriatic. Following the BiOS mechanism, however, as shown from our data, salinity and nutrient contents are out of phase due to the dynamics governing the IS circulation pattern. Therefore, the salinity variations in the Adriatic are not primarily due to the variations in the intensity of the inflow of the water through the Strait of Otranto but they are associated with different water masses entering the Adriatic. High-salinity events are thus a consequence of the inflow of salty waters from the EMed brought by the cyclonic NIG circulation, and they are at the same time poorer in nutrients due to the downwelling along the eastern flank of the Ionian.

\section{Impact of the BiOS mechanism on the Adriatic and Ionian ecosystems}

As far as the impact of the BiOS on the ecosystem is concerned, two aspects are worth mentioning: the first is the possible impact on the autotrophic biomass and on the food web due to the change in nutrient availability; the second aspect is the alternate influence of waters of Atlantic or EMed origin, bringing different types of allochtonous organisms into the Adriatic and Ionian Seas.

\subsection{Impact on the Ionian Sea}

In the past, the IS was considered remarkably oligotrophic (Boldrin et al., 2002). Recently, on the basis of ten years (1997-2007) of SeaWiFS satellite surface chlorophyll concentration observations, D'Ortenzio and Ribera d'Alcalà (2009) have divided the biogeography of the Mediterranean Sea into seven classes, assigning the class "intermittent blooming" to the area of the NIG. We interpret this quite unexpected classification as being due to the particular period in which the statistical analysis was carried out, i.e. when the NIG was cyclonic. In fact, phytoplankton blooms already reported by D'Ortenzio et al. (2003) in 1998, 1999, and 2000 were the consequence of the nutrients upwelled into the euphotic layer in the center of the cyclonic NIG (Fig. 3d). Ten years before, when the NIG was anticyclonic, according to the same authors no similar blooms were observed. The authors reported that the northwestern Ionian was the only area in the EMed showing a difference in 

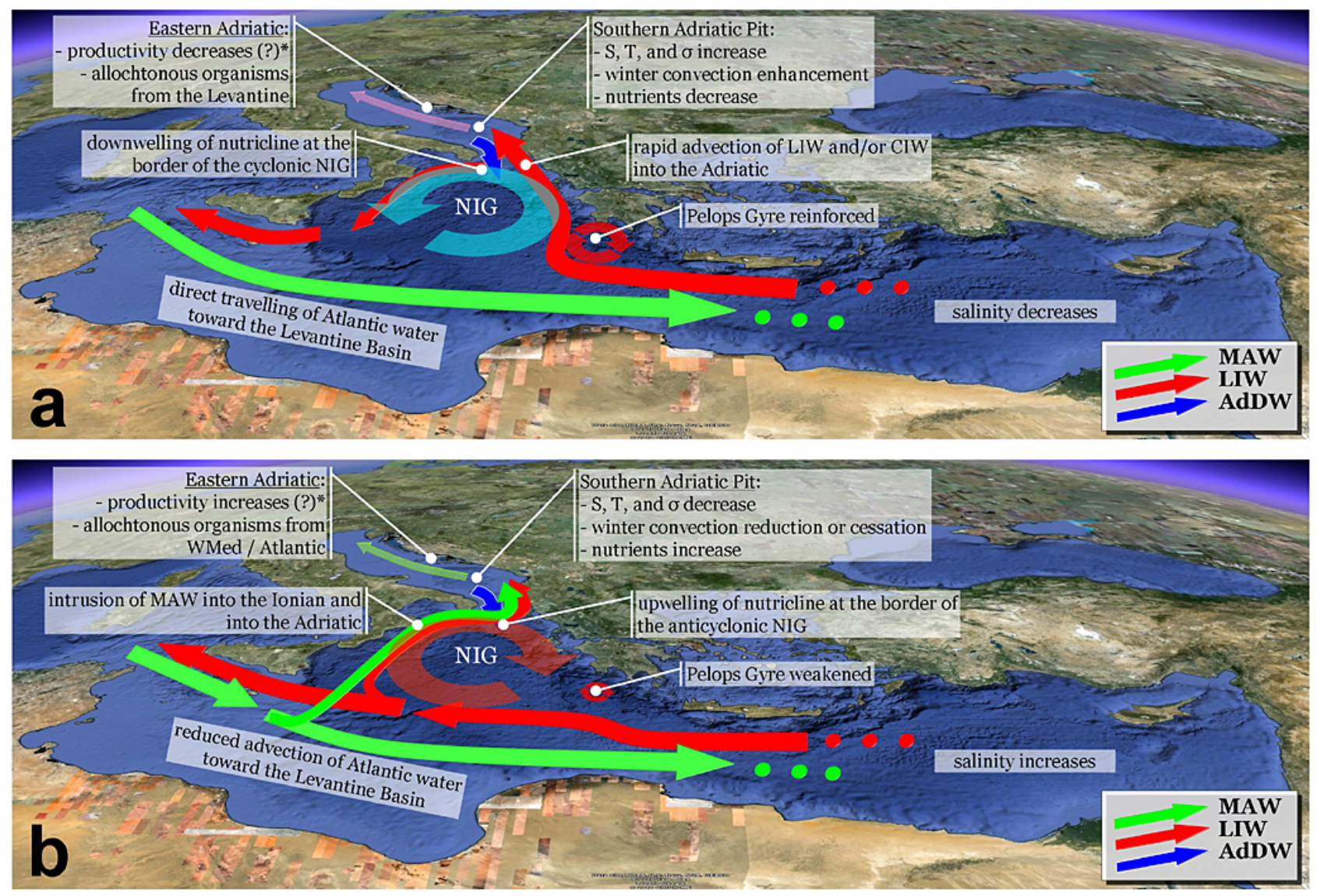

Fig. 5. Summary of the main characteristics of the Adriatic-Ionian BiOS and its impact on the area. (a) cyclonic NIG; (b) anticyclonic NIG. * For more detailed explanations, see main text (Sect. 4.2). For acronyms, see main text.

the pre-EMT and post-EMT patterns of biomass distribution. Although the authors associated this change with the uplift of the nutricline caused by the EMT, at the same time they suggested that a series of concurrent factors such as doming and convection favoured the transport of nutrients to the photic zone. We are now confident that the reversal of the NIG from an anticyclone to a cyclone by means of the BiOS mechanism created the dynamic conditions for an effective upward transfer of nutrients.

The increased autotrophic biomass following the 1997 reversal of the NIG, here attributed to the BiOS mechanism, also reflected in the abundance and composition of zooplankton communities in the IS in 1999 as described by Mazzocchi et al. (2003). The authors stressed the spatial differences occurring in the distribution of trophic groups and species in 1999 , in comparison with a more homogeneous distribution observed in spring 1992. The "classic" type of food web (phytoplankton - copepods - predators) in the northwestern Ionian, in contrast with the more oligotrophic character of the eastern Ionian (microbial links), was attributed (at least in part) by the authors to the cyclonic circulation and the related upwelling of the nutricline in the northwestern area.

\subsection{Impact on the Adriatic Sea}

In the SA, the pycnocline and the steep nutricline are typically located between 50 and $100 \mathrm{~m}$ depth (Civitarese and Gačić, 2001). These features are completely disrupted during the winter convective mixing, down to variable depths (down to $\sim 1000 \mathrm{~m}$ ), which injects nutrients into the euphotic zone. Due to the steepness of the nutricline, even weak convective mixing events are able to inject significant amounts of nutrients into the euphotic layer. When the stratification is re-established, relatively intense blooms occur (Gačić et al., 2002; Civitarese et al., 2005). After that period, the permanent stratification of the upper layer results in nutrient depletion and the establishment of stable oligotrophic conditions. Therefore, the new production of the SA is limited to winter, and mainly determined by the open-sea convection. The number of mixing-restratification events in the period March-April has great importance in determining the amount of new carbon produced (Civitarese and Gačić, 2001). 
In order to illustrate the role of the winter convective mixing in the biomass development, we report the SeaWiFS 8day average Chlorophyll- $a$ concentration time series (Fig. 4) for the area $\left(41.5^{\circ} \mathrm{N}-42.0^{\circ} \mathrm{N}, 17.5^{\circ} \mathrm{E}-18.0^{\circ} \mathrm{E}\right)$ in the SA (data produced by NASA at http://reason.gsfc.nasa.gov/OPS/ Giovanni/ocean.swf8D.2.shtml\#description). The biomass increase/accumulation in late winter/early spring is particularly evident in years 2005, 2006, and 2007 (indicated with red rectangles). This feature is typical for the convective area, being absent, for example, in the Central Adriatic (not shown), where the winter convection does not occur. Interestingly, 2005, 2006 and 2007 were also the years with maximum salinity (and nutrients minimum), as shown in Fig. 2. Higher salinity of the upper layer results in the lower buoyancy. Therefore, this suggests that the upper layer buoyancy, driven by the BiOS, is the preconditioning factor for setting the amount of primary production in the SA by determining the extent of the winter vertical mixing. The nutrient content variations, though being very strong play a secondary role.

Additionally, the picture is complicated by the fact that also the air-sea heat fluxes play an important role in the convection in the SA, as illustrated by Gačić et al. (2002). For example, the year 1999 is also characterized by a strong late winter-early spring biomass maximum. It was due to repeated intense mixing/restratification events associated with distinct and significant heat loss episodes at the end of January (Santoleri et al., 2003), although the salinity in the basin was not particularly high (Fig. 2) and the buoyancy was rather high.

To conclude, in the SA the spring primary production, being driven by the convective mixing, seems to be sensitive to the salinity (i.e. the buoyancy content in the water column), even though the heat transfer often plays a determinant role. Thus we cannot categorically state that primary production "is phased with salinity", and on the other hand any relationships with the nutrient amount in the basin can be ruled out. This makes the SA productivity particularly sensitive to the change of the meteorological and (on a larger time scale) the climatic conditions in the area on one hand, and on the buoyancy due to advection of different water masses, as dictated by $\mathrm{BiOS}$ on the other.

The winter convection results in a decrease in the nutrient pool in the SA with respect to the IS. On the other hand, when the convection is reduced or absent, as in the period 1993-1997, the two nutrient pools tend to be similar (Fig. 2) as the prevailing signal is advection from the south.

The thermohaline and biogeochemical properties of the water layer involved in the northward advection over the Palagruza Sill $(170 \mathrm{~m})$, not shown here, follow the same behaviour as the $200-800 \mathrm{~m}$ layer in the SA (Fig. 2). This could have some influence on the productivity variations in the Central Adriatic, even though the SeaWiFS Chlorophyll$a$ concentration time series does not show any significant interannual/decadal variability. However, as again our results show that nutrients and salinity are out of phase for the layer
0-170 $\mathrm{m}$ as well, a positive correlation between the salinity and primary production should be ruled out.

\subsubsection{Possible impact of the BiOS mechanism on the Adriatic biodiversity}

A number of historical observations suggest the possible impact of the change in the Ionian circulation on the abundance and species composition of marine organisms in the eastern part of the Adriatic Sea, i.e. the area characterized mostly by the northward flux of water of Ionian origin.

During the period 1961-2005, in several areas of the eastern Adriatic, changes in phyto- and zooplankton abundance and community structure (Batistić et al., 2007; Conversi et al., 2009; Degobbis et al., 1995; Kamburska and FondaUmani, 2009; Kršinić and Grbec, 2006; Ninčević Gladan et al., 2010), as well as in the quantitative and qualitative composition of the Adriatic ichthyofauna (Dulčić and Grbec, 2000; Lipej and Dulčić, 2004), have been documented and ascribed to natural and man-induced processes. Variations have been observed in biomass (Mozetić et al., 2010; Kamburska and Fonda Umani, 2009), in primary production (Grbec et al., 2009), in taxonomic composition (Ninčević Gladan et al., 2010; Conversi et al., 2009), in life cycles (Kamburska and Fonda Umani, 2009) and in ecosystem functioning (Śolić et al., 2009). The numbers of thermophilic species have increased; several species, previously scarce or rare, have become more abundant, while others have been reported for the first time. On the other hand, there are also some examples of the disappearance or increasing scarcity of some species (Batistić et al., 2007; Conversi et al., 2009).

It is well known that the biodiversity of the Mediterranean is continuously enriched by species of Indo-Pacific and Red Sea origin (Lipej et al., 2008). The process, known as Lessepsian migration, also affects the Adriatic Sea, including its northernmost portion.

These observations can be related to oceanographic changes in the Adriatic Sea (Dulčić and Grbec, 2000), to meridionalisation, i.e. temperature increase which favours spreading of species from southern to northern areas (Lipej and Dulčić, 2004), to bioinvasion due to accidental introduction of alien species (Lipej et al., 2009) and to circulation changes (Batistić et al., 2007; Conversi et al., 2009; Grbec et al., 2009; Kršinić and Grbec, 2006).

Changes in the organism abundance and in the biodiversity patterns are related to, and could perhaps be partly associated with, the circulation changes in the EMed during the last 20 years and the modification of the water masses entering the SA, as reported by Batistić et al. (2007).

More specifically, here we show that, according to their general distribution, their abundance and to the timing of their first appearance, some organisms in the Adriatic could be indicators of the inflow of WMed/Atlantic or EMed waters. In Table 2, a summary of the most significant records taken from the literature are reported. 
Table 2. Biological records and changes in NIG circulation.

\begin{tabular}{|c|c|c|c|}
\hline Date & Organism (type) & NIG circulation & Remarks \\
\hline 1982 & $\begin{array}{l}\text { Schedophilus } \\
\text { medusophagus (fish) }\end{array}$ & $?$ & $\begin{array}{l}\text { Present in the WMed. Reported in the } \\
\text { central Adriatic (Onofri, 1986). }\end{array}$ \\
\hline end of 1980's & $\begin{array}{l}\text { Copepod community } \\
\text { (mesozooplankton) }\end{array}$ & $\begin{array}{l}\text { reversal from } \\
\text { cyclonic to anticyclonic }\end{array}$ & $\begin{array}{l}\text { Changes of the entire copepod } \\
\text { community in the Gulf of Trieste } \\
\text { (Conversi et al., 2009) }\end{array}$ \\
\hline 1993 & $\begin{array}{l}\text { Desmopterus } \\
\text { papilio (gastropode) }\end{array}$ & anticyclonic & $\begin{array}{l}\text { Common in the Atlantic and } \\
\text { found in the open South Adriatic, } \\
\text { off Dubrovnik (Batistic et al., 2004) }\end{array}$ \\
\hline 1993 & $\begin{array}{l}\text { Pelagobia longicirrata } \\
\text { (polychete) }\end{array}$ & anticyclonic & $\begin{array}{l}\text { Common in the tropical Atlantic and } \\
\text { found in the open South Adriatic } \\
\text { (Batistić et al., 2004) }\end{array}$ \\
\hline 1995 & $\begin{array}{l}\text { Muggiaea atlantica } \\
\text { (hydrozoan) }\end{array}$ & anticyclonic & $\begin{array}{l}\text { Typical of the WMed. It was reported } \\
\text { for the first time in } 1995 \text { in the coastal } \\
\text { southeastern (Gamulin and Krsinic, } \\
\text { 2000), and central Adriatic (Batistić, } \\
\text { 2007), then invaded the North Adriatic } \\
\text { (Kršinić and Njire, 2001) }\end{array}$ \\
\hline end of 1990's & $\begin{array}{l}\text { Total copepod, } \\
\text { in particular } \\
\text { Paracalanus parvus } \\
\text { (mesozooplankton) }\end{array}$ & $\begin{array}{l}\text { reversal from } \\
\text { anticyclonic to cyclonic }\end{array}$ & $\begin{array}{l}\text { Changes in the abundance of some } \\
\text { species (Conversi et al., 2009) }\end{array}$ \\
\hline 2002 & Siganus rivulatus (fish) & cyclonic & $\begin{array}{l}\text { Lessepsian migrator, recorded in the } \\
\text { South Adriatic } \\
\text { (Dulčić and Pallaoro, 2004) }\end{array}$ \\
\hline 2006 & $\begin{array}{l}\text { Fistularia } \\
\text { commersonni (fish) }\end{array}$ & cyclonic & $\begin{array}{l}\text { Lessepsian migrator, caught off the } \\
\text { coastal waters in South Adriatic } \\
\text { (Dulčić et al., 2007) }\end{array}$ \\
\hline 2006 & $\begin{array}{l}\text { Thysanoteuthis rhombus } \\
\text { (cephalopode) }\end{array}$ & cyclonic & $\begin{array}{l}\text { Considered a "slow swimmer" (Marčić } \\
\text { et al., 2008), it was introduced in } \\
\text { the North Adriatic probably from the } \\
\text { Levantine basin }\end{array}$ \\
\hline 2007 & Therapon teraps (fish) & cyclonic & $\begin{array}{l}\text { Lessepsian migrator. Captured off } \\
\text { Piran, Slovenia (Lipej et al., 2008) }\end{array}$ \\
\hline
\end{tabular}

In general, from the records presented in Table 2, it follows that the presence of Atlantic and WMed species in the Adriatic is concomitant with the anticyclonic NIG and thus with advection of MAW into the Adriatic. On the other hand, records of Lessepsian organisms originating from tropical and/or temperate areas coincide with the cyclonic NIG that advects, as previously shown, EMed waters into the Adriatic, blocking the MAW intrusion.

Both advection and modification in water properties may contribute to northward expansion in species distribution. This could be the case for Muggiaea atlantica, a calycophores (Hydrozoa) recorded for the first time in the SA in winter 1995 (Gamulin and Kršinić, 2000). In July 1997, it developed successfully in the Northern Adriatic, attaining exceptionally high density, and causing a change in the structure, distribution and density of population of nauplii, copepodid stages and adult small copepods (Kršinić and Njire, 2001).

Changes in the entire copepod community that occurred in the Gulf of Trieste at the end of the 1980s and early 1990s can be associated with the change of NIG circulation in 1987 (Conversi et al., 2009). The same authors related other changes in the abundance of some species in the late 1990 s to the early 2000 s to the reversal of the NIG circulation in 1997. 
Table A1. List of acronyms.

\begin{tabular}{ll}
\hline AdDW: & Adriatic Dense Water \\
BiOS: & Bimodal Oscillating System \\
CIW: & Cretan Intermediate Water \\
CSOW: & Cretan Sea Outflow Water \\
EMDW: & Eastern Mediterranean Dense Water \\
EMed: & Eastern Mediterranean \\
EMT: & Eastern Mediterranean Transient \\
IS: & Ionian Sea \\
LIW: & Levantine Intermediate Water \\
MAW: & Modified Atlantic Water \\
NIG: & North Ionian Gyre \\
SA: & Southern Adriatic \\
WMed: & Western Mediterranean \\
\hline
\end{tabular}

The results reported in Table 2 suffer from the uncertainties typical of this kind of observation, and consequently they have to be taken into consideration with a certain caution. Nevertheless, they represent a key to the interpretation of the decadal variability in biodiversity and its effect on the local ecosystems reported in the literature during the last three decades.

\section{Summary and conclusions}

Here, experimental evidence is presented that the nitrate pool in the Southern Adriatic varied in the range $2-6 \mu \mathrm{M}$ on a decadal scale. This decadal variability is associated, through the BiOS mechanism, with the NIG circulation and the related vertical displacement of the nutricline in the Ionian Sea.

Due to the concomitant effects of the reversal of the NIG circulation and the consequent up- or downwelling at its borders, the salinity and the nutrient variations are out of phase. Consequently, a revision of the "Adriatic ingression" theory is proposed.

The reversal of the NIG in 1997 from anticyclone to cyclone, and the related shoaling of the nutricline at the center of it, driven by the BiOS mechanism, is presumably the main cause of the biomass increase in the Ionian Sea at the end of 1990s and early 2000s.

The advection of different water masses due to the BiOS mechanism results in the presence of allochtonous organisms in the Adriatic of either Atlantic/WMed or Levantine/tropical origin. The variation in biodiversity can have profound consequences on the functioning of the local ecosystem.

To conclude, we would like to cite a sentence from Buljan in his fundamental paper "Fluctuation of salinity in the Adriatic" (1953): "If we want to have a thorough knowledge of the zoogeographic distribution of single organisms in the Adriatic, or if we want to make a general study of the biology of that sea, it will not be out of place to know when, in which years, were the catches and researches carried out, as it seems that the ingressions leave a marked impression on both the quantitative and qualitative composition of popula- tions". Although referring to a mechanism here revised, i.e. the "Adriatic ingression", Buljan's words still hold their validity after more that fifty years, and should be guidelines for future research.

Acknowledgements. This work was partially supported by the European Union, under contract no. 036949-2, for the project "Southern European Seas: Assessing and Modelling Ecosystem Changes" (SESAME), and by the Italian Government for the project "Vulnerabilità delle coste e degli ecosistemi marini italiani ai cambiamenti climatici e loro ruolo nei cicli del carbonio mediterraneo" (VECTOR). Most of the experimental work carried out by C. G. took place while he was affiliated to CNR-ISMAR, Trieste (Italy).

Edited by: E. Boss

\section{References}

Batistić, M., Kršinić, F., Jasprica, N., Carić, M., Viličić, D., and Lučić, D.: Gelatinous invertebrate zooplankton of the South Adriatic: species composition and vertical distribution, J. Plankton Res., 26(4), 459-474, 2004.

Batistić, M., Jasprica, N., Carić, M., and Lučić, D.: Annual cycle of the gelatinous invertebrate zooplankton of the eastern South Adriatic coast (NE Mediterranean), J. Plankton Res., 29(8), 671686, 2007.

Boldrin, A., Miserocchi, S., Rabitti, S., Turchetto, M. M., Balboni, V., and Socal, G.: Particulate matter in the southern Adriatic and Ionian Sea: characterisation and downward fluxes, J. Marine Syst., 33-34, 389-410, 2002.

Borzelli, G. L. E., Gačić, M., Cardin, V., and Civitarese, G.: Eastern Mediterranean Transient and reversal of the Ionian Sea circulation, Geophys. Res. Lett., 36, L15108, doi:10.1029/2009GL039261, 2009.

Buljan, M.: Fluctuations of salinity in the Adriatic, Institut za Oceanografiju i Ribarstvo - Split (Croatia), Reports, II(2), 64 pp., 1953.

Civitarese, G. and Gačić, M.: Had the Eastern Mediterranean Transient an Impact on the New Production in the Southern Adriatic?, Geophys. Res. Lett., 28(8), 1627-1630, 2001.

Civitarese, G., Gačić, M., Cardin, V., and Ibello, V.: Winter Convection Continues in the Warming Southern Adriatic, EOS T. Am. Geophys. Un., 86(45), 445 and 451, 2005.

Conversi, A., Peluso, T., and Fonda-Umani, S.: Gulf of Trieste: A changing ecosystem, J. Geophys. Res., 114, C03S90, doi:10.1029/2008JC004763, 2009.

D'Ortenzio, F. and Ribera d'Alcalà, M.: On the trophic regimes of the Mediterranean Sea: a satellite analysis, Biogeosciences, 6, 139-148, doi:10.5194/bg-6-139-2009, 2009.

D’Ortenzio, F., Ragni, M., Marullo, S., and Ribera d'Alcalà, M.: Did biological activity in the Ionian Sea change after the Eastern Mediterranean Transient? Results from the analysis of remote sensing observations, J. Geophys. Res., 108(C9), 8113, doi:10.1029/2002JC001556, 2003.

Degobbis, D., Fonda-Umani, S., Franco, P., Malej, A., Precali, R., and Smodlaka, N.: Changes in the Northern Adriatic ecosystem and hypertrophic appearance of gelatinous aggregates, Sci. Total Environ., 165, 43-58, 1995. 
Dulčić, J. and Grbec, B.: Climate change and Adriatic ichthyofauna, Fish. Oceanogr., 9(2), 187-191, 2000.

Dulčić, J. and Pallaoro, A.: First record of the marbled spinefoot Siganus rivulatur (Pisces: Siganidae) in the Adriatic Sea, J. Mar. Biol. Assoc. UK, 84, 1087-1088, 2004.

Dulčić, J., Scordella, G., and Giudetti, P.: On the record of the Lessepsian migrant Fistularia commersonii (Ruppell, 1835) from the Adraitic, in: Book of Abstract, XII European Congress of Ichthyology, edited by: Buj, I., Zanella, L., and Mrakovčić, M., Zagreb: Hrvatsko ihtiološko društvo, 60-61, 2007.

Gačić, M., Civitarese, G., Miserocchi, S., Cardin, V., Crise, A., and Mauri, E.: The open-ocean convection in the Southern Adriatic: a controlling mechanism of the spring phytoplankton bloom, Cont. Shelf. Res., 22, 1897-1908, 2002.

Gačić, M., Borzelli, G. L. E., Civitarese, G., Cardin, V., and Yari, S.: Can internal processes sustain reversals of the ocean upper circulation? The Ionian Sea example, Geophys. Res. Lett., 37, L09608, doi:10.1029/2010GL043216, 2010.

Gamulin, T. and Kršinić, F.: Cylychophores (Siphonophora, Calycophorae) of the Adriatic and Mediterranean Seas, Nat. Croat., 9, 1-198, 2000.

Grasshoff, K., Eharhardt, M., and Kremlig, K. (Eds.): Methods of Seawater Analysis, 2nd edn., Verlag Chemie, Weinheim, 1983.

Grbec, B., Morović, M., Beg Paklar, G., Kušpilić, G., Matijević, S., Matić, F., and Ninčević Gladan, Ž.: The relationship between the atmospheric variability and productivity in the Adriatic Sea area, J. Mar. Biol. Assoc. UK, 89(08), 1549-1558, doi:10.1017/S0025315409000708, 2009.

Kamburska, L. and Fonda-Umani, S.: From seasonal to decadal inter-annual variability of mesozooplankton biomass in the Northern Adriatic Sea (Gulf of Trieste), J. Marine Syst., 78, 490504, 2009

Klein, B., Roether, W., Manca, B. B., Bregant, D., Beitzel, V., Kovačević, V., and Lucchetta, A.: The large deep water transient in the eastern Mediterranean, Deep-Sea Res. Pt. I, 46, 371-414, doi:10.1016/S0967-0637(98)00075-2, 1999.

Kršinić, F. and Grbec, B.: Horizontal distribution of tintinnids in the open waters of the South Adriatic (Eastern Mediterranean), Sci. Mar., 70(1), 77-88, 2006.

Kršinić, F., Njire, J.: An invasion by Muggiaea atlantica CUNNINGHAM 1892 in the northern Adriatic Sea in the summer of 1997 and the fate of small copepods, Acta Adriat., 42(1), 49-59, 2001.

Larnicol, G., Ayoub, N., and Le Traon, P. Y.: Major changes in Mediterranean Sea level variability from 7 years of TOPEX/Poseidon and ERS-1/2 data, J. Marine Syst., 33-34, 63 89, 2002.

Lipej, L. and Dulčić, J.: The current status of the Adriatic fish biodiversity, in: Balkan Biodiversity: pattern and process in the European hotspot, edited by: Griffiths, H. I., Kryštufek, B., and Reed, J. M., Kluwer Academic Publishers, Dordrecht, Boston, London, 291-306, 2004.

Lipej, L., Mavrič, B., Žiža, V., and Dulčić, J.: The largescaled terapon Terapon theraps: a new Indo-Pacific fish in the Mediterranean Sea, J. Fish Biol., 73, 1819-1822, 2008.

Lipej, L., Mavrič, B., and Orlando Bonaca, M.: Recent changes in the Adriatic fish fauna - experiences from Slovenia, Varstvo Narave, 22, 91-96, 2009.

Malanotte-Rizzoli, P., Manca, B. B., Ribera d'Alcalà, M., Theo- caris, A., Bergamasco, A., Bregant, D., Budillon, G., Civitarese, G., Georgopoulos, D., Michelato, A., Sansone, E., Scarazzato, P., and Souvermezoglou, E.: A synthesis of the Ionian Sea hydrography, circulation and water mass pathways during POEM - phase I, Prog. Oceanogr., 39, 153-204, doi:10.1016/S00796611(97)00013-X, 1997.

Malanotte-Rizzoli, P., Manca, B. B., Ribera d'Alcalà, M., Theocharis, A., Brenner, S., Budillon, G., and Ozsoy, E.: The Eastern Mediterranean in the 80s and in the 90s: The big transition in the intermediate and deep circulations, Dynam. Atmos. Oceans, 29, 365-395, doi:10.1016/S0377-0265(99)00011$1,1999$.

Manca, B. B., Ursella, L., and Scarazzato, P.: New development of Eastern Mediterranean circulation based on hydrological observations and current measurements, Mar. Ecol., 23, Suppl. 1, 237-257, 2002.

Marasović, I., Grbec, B., and Morović, M.: Long-term production changes in the Adriatic, Neth. J. Sea Res., 34(4), 267-273, 1995.

Marčić, Z., Čaleta, M., Buj, I., Mrakovčić, M., Mustafić, P., Zanella, D., and Dulčić, J.: First record of Thysanoteuthis rhombus (Cephalopoda: Thysanoteuthidae) in the Adriatic Sea, J. Mar. Biol. Assoc. UK, 2 - Biodiversity Records, 1-3, 2008.

Marullo, S., Santoleri, R., Malanotte-Rizzoli, P., and Bergamasco, A.: The sea surface temperature field in the east Mediterranean Sea from AVHRR data. Part I. Seasonal variability, J. Marine Syst., 33-34, 63-89, 1997.

Mazzocchi, M. G., Nervegna, D., D’Elia, G., Di Capua, I., Aguzzi, L., and Boldrin, A.: Spring mesozooplankton communities in the epipelagic Ionian Sea in relation to the Eastern Mediterranean Transient, J. Geophys. Res., 108(C9), 8114, doi:10.1029/2002JC001640, 2003.

Mozetič, P., Solidoro, C., Cossarini, G., Socal, G., Precali, R., Francé, J., Bianchi, F., Smodlaka, N., De Vittor, C., and FondaUmani, S.: Recent trends towards oligotrophication of the northern Adriatic: evidence from chlorophyll a time series, Estuar. Coast., 33, 362-375, 2010

Ninčević Gladan, Z., Marasović, I., Grbec, B., Skejić, S., Bužančić, M., Kušpilić, G., Matijević, S., and Matić, F.: Inter-decadal Variability in Phytoplankton Community in the Middle Adriatic (Kaštela Bay) in Relation to the North Atlantic Oscillation, Estuar. Coast., 33, 376-383, 2010.

Onofri, I.: The rare fish "trnobraz" (Schedophilus medusophagus Cocco, 1893) (Pisces: Centrolophidae) in the Middle Adriatic, Matica srpska, 70, 135-141, 1986.

Roether, W., Manca, B. B., Klein, B., Bregant, D., Georgopoulos, D., Beitzel, V., Kovačević, V., and Lucchetta, A.: Recent changes in eastern Mediterranean deep waters, Science, 271, 333-335, doi:10.1126/science.271.5247.333, 1996.

Santoleri, R., Banzon, V., Marullo, S., Napolitano, E., D’Ortenzio, F., and Evans, R.: Year-to-year variability of thephytoplankton bloom in the southern Adriatic Sea (1998-2000): Sea-viewing Wide Field-of-view Sensor observations and modeling study, J. Geophys. Res., 108(C9), 8122, doi:10.1029/2002JC001636, 2003.

Šolić, M., Krstulović, N., Vilibić, I., Bojanić, N., Kušpilić, G., Šestanović, S., Šantić, D., and Ordulj, M.: Variability in the bottom-up and top-down controls of bacteria on trophic and temporal scales in the middle Adriatic Sea, Aquat. Microb. Ecol., 58, 15-29, 2009. 